\title{
Penerapan Model Problem Based Learning berbantuan Mind Mapping untuk Meningkatkan Hasil Belajar Termodinamika
}

\author{
$\operatorname{Yadi}^{(1)}$ \\ ${ }^{1}$ SMA Negeri 1 Kalidawir, \\ Email: ${ }^{1}$ yadi.kalidawir@gmail.com
}

\begin{abstract}
ABSTRAK
Dalam rangka meningkatkan prestasi belajar Fisika yang memuat Termodinamika pada Siswa Kelas XI IPA 2 SMA Negeri 1 Kalidawir Tulungagung, Peneliti melakukan penelitian tindakan kelas dengan menerapkan pendekatan Problems Based Learning berbantuan dengan Metode Mind Mapping pada pembelajaran Fisika. Sasaran penelitian ini adalah siswa Kelas XI IPA 2 SMA Negeri 1 Kalidawir Tulungagung yang berjumlah 35 siswa. Berdasarkan hasil observasi yang dilakukan di Kelas XI IPA 2 pada waktu pembelajaran Fisika diperoleh hasil bahwa prestasi belajar siswa kurang memuaskan, yaitu dari 35 siswa hanya 14 siswa yang nilainya dapat mencapai KKM atau $\geq 70$, sedangkan 21 siswa lainnya masih belum dapat mencapai KKM atau $\leq 69$. Simpulan dari penelitian ini adalah pendekatan Problems Based Learning berbantuan dengan Metode Mind Mapping dapat meningkatkan prestasi belajar siswa pada pembelajaran Fisika yang memuat Termodinamika.
\end{abstract}

Kata kunci: Prestasi belajar, Termodinamika, Pendekatan Problems Based Learning berbantuan dengan Metode Mind Mapping,

\section{PENDAHULUAN}

Pembelajaran Fisika sebagian besar masih dilakukan secara tradisional yang terbatas pada konsep dan teori, hal ini yang mengakibatkan siswa kurang tertarik mempelajari Fisika. Bertolak dari hal itu, maka peningkatan kualitas pembelajaran harus dilakukan. Untuk itu diupayakan suatu model pembelajaran yang dapat mendukung keaktifan siswa sehingga proses interaksi dalam pembelajaran Fisika dapat berlangsung sempurna. Fisika adalah mata pelajaran yang banyak menuntut intelektualitas yang relatif tinggi sehingga sebagian besar siswa mengalami kesulitan mempelajarinya. Keadaan yang demikian ini lebih diperparah lagi dengan penggunaan Metode pembelajaran Fisika yang tidak tepat.

Dari informasi yang di peroleh dari guru fisika di SMA Negeri 1 Kalidawir, pembelajaran fisika yang selama ini sudah dilaksanakan di SMA Negeri 1 Kalidawir menggunakan Metode ceramah yang terkadang diselingi dengan diskusi kelompok (pembelajaran kooperatif) dan masih menerapkan keaktifan guru dalam kegiatan pembelajarannya. Pembelajaran cenderung bersifat informatif sehingga keterlibatan siswa secara aktif dalam proses pembelajaran masih kurang. Kondisi yang demikian akan membuat siswa kurang termotivasi untuk belajar. Hal ini terbukti dengan perilaku siswa yang kurang bersemangat dalam mengikuti kegiatan belajar di kelas sehingga nilai siswa pada mata pelajaran fisika kurang memuaskan. Agar tujuan pembelajaran fisika di SMA dapat dicapai maka perlu adanya inovasi dalam proses pembelajaran fisika di kelas. Inovasi tersebut dapat berupa model pembelajaran yang bisa membuat siswa menjadi lebih aktif dan bersemangat dalam melakukan proses pembelajaran.

Dalam proses pembelajaran di kelas sering timbul masalah yang pada umumnya dialami oleh siswa. Masalah yang dihadapi siswa bersifat unik berbeda satu sama lain. Misalnya masalah dan kesulitan ataupun rendahnya prestasi belajar yang dialami siswa pada mata pelajaran Fisika bisa terjadi karena berbagai faktor diantaranya, keterbatasan kemampuan, keadaan, minat dan motivasi diri siswa itu sendiri, situasi belajar di sekolah atau kelas dan kurangnya sarana dan prasarana, 
materi pelajaran yang kurang relevan dengan kebutuhan siswa dan pendekatan mengajar yang kurang bisa dipahami siswa bahkan kurangnya alat peraga dan alat bantu mengajar.

Apalagi mata pelajaran Fisika menuntut kemampuan Guru untuk bisa membuat siswa mengerti dan memahami tentang materi yang diajarkan dengan tidak hanya membaca buku dan teori saja melainkan harus disertai alat peraga, contoh, praktek, latihan soal, seperti soal bercerita dan sebagainya, agar siswa memiliki pengetahuan, keterampilan dan bahkan sikap ilmiah yang berujung pada pemerolehan Prestasi Belajar yang maksimal..

Berdasarkan hasil pengamatan dalam proses belajar mengajar dikelas, keadaan sekolah, dan melalui peninjauan bidang akademik dan non akademik, diperoleh hasil bahwa keadaan Sekolah Menengah Atas Negeri 1 Kalidawir khususnya siswa Kelas XI IPA 2 tahun ajaran 2015/2016 dalam pelajaran Fisika belum menunjukkan Prestasi Belajar sesuai dengan KKM yang ditetapkan terutama pada materi pelajaran Termodinamika. Padahal, ditinjau dari keadaan fisik sekolah, yaitu ruang Kelas XI IPA 2 sudah baik dan sesuai sebagai tempat berlangsungnya proses belajar mengajar. Pengamatan pada proses pembelajaran oleh peneliti dapat disimpulkan bahwa pelaksanaan proses belajar mengajar lah yang belum membuat siswa aktif belajar, sehingga kemampuan siswa belum tergali dengan maksimal.

Pada ulangan harian Fisika dengan materi Termodinamika, di dapat rata-rata nilai sebesar 64 dari 35 siswa, padahal Kriteria Ketuntasan Minimalnya (KKM) telah ditentukan nilai sebesar 70. Dan hanya 14 siswa yang mendapat nilai di atas 70 . Hal ini berarti, hanya $40 \%$ dari siswa yang telah mencapai ketuntasan belajar, dan yang lainnya memiliki prestasi belajar yang rendah.

Dari hasil diskusi dengan teman sejawat ditemukan masalah-masalah dalam proses pembelajaran Fisika yang menyebabkan menurunkan prestasi belajar adalah materi kurang dapat dikuasi siswa secara optimal, penggunaan pendekatan pembelajaran dalam pembelajaran Fisika pada siswa Kelas XI IPA 2 belum sesuai, siswa terlihat tidak antusias untuk belajar dan pembelajaran dengan pendekatan konvensional yaitu dengan menjelaskan materi dan siswa hanya melakukan perintah mengerjakan soal tanpa penanaman konsep pembelajaran yang kuat terlihat tidak efektif dalam proses peningkatan prestasi belajar siswa.

Oleh karena itu, demi memperbaiki berbagai masalah yang ada, peneliti memerlukan suatu solusi untuk mengatasi hambatan-hambatan yang terjadi, peneliti menggunakan pendekatan Problems Based Learning berbantuan dengan Metode Mind Mapping dalam pembelajaran Fisika ini. Metode Problems Based Learning berbantuan dengan Metode Mind Mapping adalah siswa akan bekerja secara kooperatif dalam kumpulan untuk menyelesaikan masalah sebenarnya dan yang paling penting membina kemahiran untuk menjadi siswa yang belajar secara sendiri.

Metode Problems Based Learning berbantuan dengan Metode Mind Mapping merupakan kemampuan berpikir siswa secara kritis dan kontinu berkaitan dengan ide yang dihasilkan serta yang akan dilakukan. Dalam melaksanakan proses pembelajaran Problems Based Learning berbantuan dengan Metode Mind Mapping, akan tetapi bagaimana mereka dapat menggunakan kemampuan yang dimilikinya secara optimal.

Rumusan masalah dari penelitian ini adalah Bagaimana penerapan pendekatan Problems Based Learning berbantuan dengan Metode Mind Mapping untuk meningkatkan Prestasi Belajar Fisika penguasaan Termodinamika pada Siswa Kelas XI IPA 2 SMA Negeri Kalidawir 1 Kecamatan Kalidawir Kabupaten Tulungagung?

Apakah penerapan pendekatan Problems Based Learning berbantuan dengan Metode Mind Mapping dapat meningkatkan Prestasi Belajar Fisika materi Termodinamika pada Siswa Kelas XI IPA 2 SMA Negeri Kalidawir 1 Kecamatan Kalidawir Kabupaten Tulungagung?

Tujuan dari penelitian ini adalah mendeskripsikan penerapan Pendekatan Problems Based Learning berbantuan dengan Metode Mind Mapping pada Siswa 
Vol. 1 No. 1, Oktober 2017

Kelas XI IPA 2 SMA Negeri 1 Kalidawir Tulungagung, dan meningkatkan prestasi belajar siswa pada Fisika yang memuat Termodinamika melalui penerapan Pendekatan Problems Based Learning berbantuan dengan Metode Mind Mapping pada Siswa Kelas XI IPA 2 SMA Negeri 1 Kalidawir Tulungagung.

Dalam pelaksanaan penelitian ini, peneliti berharap dapat memberikan manfaat bagi: 1) Peneliti (Guru) adalah (a) Sebagai saranan peningkatan mutu, ilmu pengetahuan, pendekatan dan seni mengajar (b) Sebagai jembatan bagi Guru agar lebih mudah berkomunikasi dengan siswa (c) Sebagai acuan dan bahan tinjauan dalam pembinaan dan penilaian terhadap Proses Belajar Mengajar (PBM) yang dilaksanakan Guru di sekolah (d) Hasil penelitian ini dapat dijadikan sebagai masukan untuk meningkatkan mutu dan kualitas pembelajaran di kelas. (2) Manfaat penelitian ini bagi siswa adalah: (a) Siswa dapat lebih mudah memahami materi pelajaran (b) Siswa lebih berani dalam bereksperimen dan menemukan hal baru (c) Dapat meningkatkan kemampuan siswa dalam menerima pembelajaran sehingga prestasi belajar siswa pun menjadi lebih baik. (3) Manfaat penelitian ini bagi peneliti lain adalah hasil penelitian dapat dijadikan acuan dalam melakukan penelitian yang sejenis dan (4) Manfaat penelitian ini bagi kepala sekolah adalah hasil penelitian ini dapat dijadikan acuan dalam membuat kebijakan tentang peningkatan kualitas sekolah.

\section{METODE \\ Subjek, Tempat dan Waktu Penelitian}

Lokasi yang digunakan tempat penelitian adalah ruang Kelas XI IPA 2 Sekolah Menengah Atas Negeri 1 Kalidawir Kecamatan Kalidawir Kabupaten Tulungagung Tahun Pelajaran 2015/2016. Dalam penelitian ini subjek yang digunakan adalah seluruh siswa Kelas XI IPA 2 Sekolah Menengah Atas Negeri 1 Kalidawir Kecamatan Kalidawir Kabupaten Tulungagung sebanyak 35 siswa yang terdiri dari 18 siswa putra dan 17 siswa putri.

Penelitian dilaksanakan pada semester 2, adapun pada siklus pertama dilaksanakan pada hari Selasa, 12 April 2016 dan siklus kedua dilaksanakan pada hari Selasa, 19 April 2016.

\section{Desain Prosedur Perbaikan Pembelajaran}

Penelitian ini menggunakan pendekatan penelitian kualitatif dengan pendekatan penelitian tindakan kelas karena penelitian ini dilaksanakan berdasarkan adanya temuan masalah di kelas. Berdasarkan variable yang diteliti dan tujuan yang hendak dicapai, maka pendekatan penelitian yang digunakan adalah dengan sistem spiral. Stephen Kemmis dan Robin Mc Taggart tahun 1988 mengembangkan model Kurt Lewin dalam suatu sistem spiral dengan empat komponen utama, yakni perencanaan (planning), tindakan (acting), observasi (observing) dan refleksi (reflecting). Tahap pelaksanaan tindakan yaitu merupakan suatu hal yang dilakukan sebagai upaya perubahan yang dilakukan. Tahap observasi atau pengamatan yaitu mengamati secara sistematis hasil atau dampak tindakan terhadap proses belajarmengajar, dan tahap refleksi yaitu mengkaji dan mempertimbangkan hasil atau dampak tindakan yang dilakukan.

Peneliti dalam penelitian kualitatif berperan sebagai instrument penelitian, kehadiran peneliti mutlak diperlukan, dalam hal ini peneliti bertindak sebagai perencana, pelaksanaan pengajaran, pengumpul data, penganalisis, penafsir dan sebagai pelapor hasil penelitian. Peneliti berkolaborasi dengan teman sejawat sebagai observer. Penelitian ini bertempat di SMA Negeri 1 Kalidawir Kabupaten Tulungagung. SMA Negeri ini termasuk lembaga pendidikan yang memiliki hasil output bagus dilingkup sekitarnya. Namun terlihat nilai pembelajaran Fisika di Kelas XI IPA 2 belum maksimal, Guru lebih banyak berceramah, siswa hanya sebagai pendengar, kondisi seperti ini mengakibatkan siswa merasa bosan dan enggan belajar Fisika dan susah dalam mengerjakan soal-soal Fisika khususnya Termodinamika. Selain itu, dilihat bahwa nilai Fisika siswa masih belum menggembirakan karena masih terdapat siswa 
yang nilainya berada di bawah KKM. Dalam pelaksanaan Penelitian Perbaikan Pembelajaran ini yang akan menjadi subjek adalah Siswa Kelas XI IPA 2 SMA Negeri 1 Kalidawir Tulungagung, yang berjumlah 35 siswa.

Berdasarkan hasil pengidentifikasian dan penetapan masalah, peneliti kemudian mengajukan suatu solusi yang berupa penerapan Pendekatan Problems Based Learning berbantuan dengan Metode Mind Mapping yang dapat dimanfaatkan Guru untuk digunakan sebagai pendekatan pengajaran dalam pembelajaran Fisika Kelas XI IPA 2 SMA Negeri 1 Kalidawir Kecamatan Kalidawir Tulungagung. Penelitian ini dilakukan dengan dua siklus, dimana masing-masing siklus dikenai perlakuan yang sejenis dengan bobot yang beda. Dibuat dua siklus dimaksudkan untuk memperbaiki system pengajaran yang dilaksanakan.. Pelaksanaan tindakan pada siklus 1 dan siklus 2 dibagi menjadi 4 tahapan yaitu (1) Persiapan awal, (2) pertemuan awal, (3) proses supervisi (observasi), dan (4) pertemuan balikan atau refkleksi.

Pengumpulan data dalam penelitian ini dapat dilakukan dengan menggunakan teknik observasi, angket, dokumentasi, tes, wawancara, dan catatan lapangan. Teknik analisis data yang digunakan dalam penelitian ini adalah teknik analisis data kualitatif yaitu menggambarkan kenyataan atau data sesuai dengan data yang diperoleh dengan tujuan untuk mengetahui peningkatan kualitas kinerja guru. Langkah-langkah analisis terdiri dari tiga alur kegiatan yang terjadi secara bersamaan yaitu: (1) reduksi data, (2) penyajian data, (3) penarikan kesimpulan.

Pada kegiatan reduksi data, peneliti mengumpulkan pelaksanaan pengembangan pembelajaran menggunakan pendekatan Problems Based Learning berbantuan dengan Metode Mind Mapping dan hasil belajar siswa Data hasil reduksi yaitu pelaksanaan pengembangan pembelajaran menggunakan pendekatan Problems Based Learning berbantuan dengan Metode Mind Mapping pada siklus 1 dan 2, data hasil observasi Guru pada siklus 1 dan siklus 2. Kegiatan penyajian data dilakukan dalam rangka mengorganisasikan hasil reduksi, dengan menyusun secara narasi sekumpulan informasi yang diperoleh dari hasil reduksi hingga memberi kemungkinan adanya penarikan kesimpulan dan pengambilan tindakan. Informasi yang dimaksud adalah apakah penerapan pendekatan Problems Based Learning berbantuan dengan Metode Mind Mapping dapat meningkatkan prestasi belajar siswa, Pengelolaan pembelajaran oleh Guru, respon siswa terhadap kegiatan pembelajaran, serta hasil yang diperoleh sebagai akibat dari pemberian tindakan. Sajian data selanjutnya ditafsirkan dan dievaluasi untuk merencanakan tindakan selanjutnya.

\section{Teknik Analisis Data}

Teknik analisis yang digunakan yaitu deskriptif persentase. Data hasil penelitian yang dianalisis meliputi rata-rata kelas, ketuntasan belajar individu dan ketuntasan belajar secara klasikal. Selanjutnya hasil analisis data diperoleh baik secara kualitatif (dengan kata-kata) dan kuantitatif (dengan grafik). Hasil ini diinterprestasikan dan disimpulkan untuk menjawab permasalahan yang ada

Kegiatan penarikan kesimpulan mencakup pencarian arti dan makna data serta memberi penjelasan. Makna dan arti yang diperoleh tersebut harus di uji kebenarannya serta kecocokannya melalui kegiatan verifikasi. Verifikasi tersebut merupakan validitas data yang disimpulkan. Hasil analisis data ini akan dijadikan dasar untuk menentukan keberhasilan pemberian tindakan. Selain itu analisis data ini akan digunakan dasar untuk melaksanakan tindakan selanjutnya, jika pemberian tindakan sebelumnya tidak berhasil. Berdasarkan analisis maka akan ditentukan mana yang perlu dilakukan perbaikan untuk pelaksanaan tindakan selanjutnya. Penarikan kesimpulan dilihat dari hasil ketuntasan belajar siswa baik secara individu maupun kelompok selama pembelajaran dengan menggunakan pengembangan pendekatan Problems Based Learning berbantuan dengan Metode Mind Mapping.

Patokan penilaian yang digunakan adalah target indikator pencapaian persentase target ketercapaian pada indikator yang ditetapkan dalam penelitian ini berdasarkan pada hasil observasi yang dilakukan baik pra siklus, siklus 1 ataupun 
siklus 2, dikatakan indikator tercapai bila 85\% dari siswa Kelas XI IPA 2 mendapat nilai Fisika minimal di atas KKM atau 70

Evaluasi dilaksanakan setelah diperoleh hasil analisis yang akurat. Kegiatan evaluasi dilakukan untuk mengetahui keberhasilan penelitian dalam meningkatkan hasil belajar siswa melalui pembelajaran menggunakan pendekatan Problems Based Learning berbantuan dengan Metode Mind Mapping pada pembelajaran Fisika materi Termodinamika, jika hasil penelitian belum sesuai dengan harapan, maka akan dicari penyebabnya. Untuk itu dalam penelitian juga diperlukan refleksi. Refleksi merupakan kegiatan memikirkan atau merenungkan kembali semua kegiatan yang telah dilakukan, kemudian mencari solusi perbaikan yang dapat dilakukan untuk meningkatkan keberhasilan tindakan yang dilakukan.

\section{HASIL \\ Paparan Data Observasi Pra Siklus}

Sebelum melaksanakan proses penelitian, peneliti mengumpulkan data dan informasi tentang subjek penelitian. Data-data yang dikumpulkan antara lain daftar nama siswa Kelas XI IPA 2, daftar nilai ulangan harian Fisika materi Termodinamika, hasil wawancara dengan informan yaitu siswa Kelas XI IPA 2 SMA Negeri 1 Kalidawir Kecamatan Kalidawir Kabupaten Tulungagung. Dari pengumpulan data, nilai ulangan harian tentang Termodinamika, rata-rata nilai yang didapat hanya sebesar 64. Dari 35 siswa, hanya 14 siswa yang mendapat nilai di atas 70 . Ini berarti hanya $40 \%$ siswa yang telah mencapai ketuntasan belajar, karena Kriteria Ketuntasan Minimal (KKM) telah ditentukan sebesar 70 .

Daftar frekuensi nilai ulangan harian Fisika Termodinamika siswa Kelas XI IPA 2 SMA Negeri 1Kalidawir Kecamatan Kalidawir Tulungagung pada kondisi awal adalah terdapat 1 siswa atau $3,1 \%$ yang mendapat nilai antara $0-40$, ada 20 siswa atau $57,1 \%$ yang mendapat nilai antara 41 - 69, dan ada 14 siswa atau $40 \%$ yang mendapat nilai antara 70 - 100. Dengan ketentuan nilai KKM 70, maka dapat disimpulkan jika pencapaian prestasi nilai $70-100$ yang hanya $40 \%$ merupakan prestasi yang rendah.

Selain itu, dari proses wawancara diperoleh kesimpulan bahwa siswa kurang berminat dalam melaksanakan kegiatan pembelajaran, serta dalam pembelajaran Guru lebih sering menggunakan ceramah sehingga siswa merasa jenuh dan bosan, akibatnya minat siswa untuk belajar Fisika terutama pada Termodinamika menjadi berkurang sehingga mempengaruhi hasil prestasinya

Berdasarkan hasil data yang dikumpulkan, dapat dikemukakan dua hal pokok yang perlu diatasi, yaitu menumbuhkan minat siswa untuk belajar Fisika dan memahamkan Termodinamika dengan cara mengaktifkan siswa dalam kegiatan belajar mengajar dan meningkatkan prestasi belajar siswa dengan menerapkan Pendekatan Problems Based Learning berbantuan dengan Metode Mind Mapping pada siklus 1 nanti dengan harapan prestasi belajar siswa dapat meningkat. Untuk itu perlu dilaksanakan perbaikan pembelajaran pada siklus 1 dan jika belum tuntas maka akan dilanjutkan pada siklus 2 .

\section{Tinjauan Siklus 1}

Pelaksanaan siklus I yang dilaksanakan pada hari Selasa tanggal 12 April 2016 di ruang Kelas XI IPA 2 SMA Negeri 1 Kalidawir Kecamatan Kalidawir Kabupaten Tulungagung pada jam pertama dan kedua. Pertemuan direncanakan berlangsung 2x45 menit dilaksanakan pada jadwal terstruktur. Proses belajar mengajar mengacu pada rencana pembelajaran yang telah dipersiapkan.

Langkah peneliti antara lain adalah menyiapkan instrument penelitian, dan bahan ajar salah satunya Rencana Pelaksanaan Pembelajaran Siklus I materi pelajaran Fisika Kelas XI IPA 2 semester 2, dengan Kompetensi Dasar 3.2 Menganalisis perubahan keadaan gas ideal dengan menerapkan hukum termodinamika. Mempersiapkan pula silabus, materi pelajaran, tugas kelompok atau 
lembar kegiatan, post test. Peneliti juga menyiapkan evaluasi, evaluasi digunakan peneliti untuk mengukur sejauh mana keberhasilan proses pembelajaran. Peneliti pun menyiapkan lembar observasi, untuk mengamati proses pembelajaran dan lembar angket untuk mengetahui hasil pendekatan pembelajaran.

Kegiatan diawali dengan menjelaskan tentang pendekatan yang akan digunakan yaitu Pendekatan Problems Based Learning berbantuan dengan Metode Mind Mapping dan komponen-komponennya kepada siswa. Guru membuka pelajaran dengan mengucapkan salam. Guru memberikan apersepsi kalimat Termodinamika, "Apa yang dimaksud Proses isotermal?"

Setelah itu, siswa dibagi ke dalam 5 (lima) kelompok sesuai absensi, setelah itu Guru atau Peneliti memberikan penjelasan tentang tujuan pembelajaran dan garis besar Termodinamika. Setelah siswa bergabung ke dalam kelompoknya masingmasing. Guru atau Peneliti membagi tugas kepada setiap kelompok. Secara berkelompok, siswa mendapat tugas untuk membuat percobaan Hukum Termodinamika I.

Dalam pelaksanaan kegiatan percobaan, Guru memberi bimbingan. Secara berkelompok, siswa menyelesaikan percobaan Hukum Termodinamika I, pelaksanaan percobaan ini sebagai penerapan awal Model Pembelajaran Problems Based Learning berbantuan dengan Metode Mind Mapping. (Pelaksanaan percobaan merupakan penerapan Model Pembelajaran Problems Based Learning berbantuan dengan Metode Mind Mapping digunakan untuk menguji jawaban sementara)

Setelah kegiatan kelompok selesai, dilanjutkan dengan diskusi kelas yang dipandu oleh Guru untuk membahas hal-hal yang tidak atau belum terselesaikan dalam kegiatan kelompok. Guru secara bergilir mendekati masing-masing kelompok untuk memberikan penguat serta penjelasan sesuatu hal yang belum dipahami oleh siswa (Kegiatan diskusi adalah kegiatan Pendekatan Problems Based Learning berbantuan dengan Metode Mind Mapping menarik kesimpulan)

Guru atau peneliti membacakan hasil diskusi di depan kelas. Guru selaku moderator dalam diskusi akan memberikan kesempatan kepada kelompok lain untuk memberikan tanggapan atas pernyataan tersebut. Guru secara bergilir mendekati masing-masing kelompok untuk memberikan penguat serta penjelasan sesuatu hal yang belum dipahami oleh siswa (Kegiatan diskusi adalah kegiatan Pendekatan Problems Based Learning berbantuan dengan Metode Mind Mapping menarik kesimpulan). Guru akan memberikan kesempatan bertanya kepada siswa tentang materi yang belum dimengerti. Secara bersama-sama, Guru mengambil simpulan dan mendiskusikannya bersama siswa. Guru memberikan post tes atau quis untuk mengukur keberhasilan yang dicapai siswa. (lembar soal dapat dilihat di lampiran). Sehingga bisa dilihat peningkatan prestasi belajarnya.

terdapat 13 siswa atau 37,1\% yang mendapat nilai antara $41-69$, dan 22 siswa atau $62,9 \%$ yang mendapat nilai antara $70-100$. Dengan ketentuan nilai KKM 70 , dapat disimpulkan jika pencapaian prestasi nilai $70-100$, maka prestasi belajar siswa telah meningkat dari $40 \%$ menjadi $62,9 \%$. Namun karena belum mencapai target indicator pencapaian siklus I sebesar $85 \%$ atau lebih, maka akan dilanjutkan ke Siklus II.

Selain itu, dari proses wawancara diperoleh kesimpulan bahwa beberapa siswa menjadi bersemangat dalam belajar Fisika, karena pelaksanaan kegiatan belajar Fisika dengan Pendekatan Problems Based Learning berbantuan dengan Metode Mind Mapping ini dilaksanakan dengan langsung secara mandiri oleh siswa, dan melaksanakan kegiatan bersama kelompok sehingga lebih ringan. Meskipun masih terdapat kendala-kendala seperti yang telah diuraikan dalam laporan observasi.

\section{Tinjauan Siklus 2}

Berdasarkan hasil refleksi pada siklus I, disepakati bahwa siklus kedua perlu dilaksanakan. Pelaksanaan siklus II yang dilaksanakan pada hari Selasa, tanggal 19 April 2016 di SMA Negeri 1 Kalidawir Kecamatan Kalidawir Kabupaten Tulungagung 
pada jam pertama dan kedua. Pertemuan direncanakan berlangsung 2x45 menit dilaksanakan pada jadwal terstruktur. Proses belajar mengajar mengacu pada rencana pembelajaran yang telah dipersiapkan. Pengamatan (observasi) dilaksanakan bersamaan dengan pelaksaaan belajar mengajar.

Pada siklus 2 ini, Guru lebih memperhatikan dan mendekati siswa dan kelompok yang memerlukan bimbingan, Guru memberi bimbingan bagi siswa dan kelompok yang memerlukan, Guru memandu siswa dalam melaksanakan percobaan, Guru mengganti rencana pembelajaran Model Pembelajaran Problems Based Learning berbantuan dengan Metode Mind Mapping baru yaitu dengan memberikan tugas kepada masing-masing siswa ditugaskan untuk melakukan percobaan Hukum Termodinamika II; Guru memilihkan kelompok berdasarkan kelompok pada siklus 1.

Karena pada siklus I diketahui masih banyak siswa yang malu untuk maju presentasi dan mengajukan pertanyaan, maka pada siklus II ini Guru memberikan reward kepada siswa yang mau maju presentasi dan aktif dalam diskusi baik bertanya maupun menjawab pertanyaan

Langkah peneliti antara lain adalah menyiapkan instrument penelitian, dan bahan ajar salah satunya Rencana Pelaksanaan Pembelajaran Siklus II Mata pelajaran Fisika Kelas XI IPA 2 semester 2, dengan Kompetensi Dasar 3.2 Menganalisis perubahan keadaan gas ideal dengan menerapkan hukum termodinamika. Mempersiapkan pula silabus, materi pelajaran, tugas kelompok atau lembar kegiatan, post test. Peneliti juga menyiapkan evaluasi soal, evaluasi digunakan peneliti untuk mengukur sejauh mana keberhasilan proses pembelajaran. Peneliti pun menyiapkan lembar observasi, untuk mengamati proses pembelajaran dan lembar angket untuk mengetahui hasil pendekatan pembelajaran

Langkah-langkah yang dilakukan Guru dalam pelaksanaan siklus II ini antara lain, kegiatan diawali dengan Guru membuka pelajaran dengan mengucapkan salam; Guru mengulang materi yang lampau yang berkaitan dengan materi yang akan disampaikan sekarang; Memberikan apersepsi, soal pemanasan untuk siswa seperti Apa yang dimaksud Termodinamika?"

Menjelaskan kembali tentang Metode yang akan digunakan yaitu Metode Problems Based Learning berbantuan dengan Metode Mind Mapping dan komponenkomponennya kepada siswa. Siswa menuju kelompoknya masing-masing, setelah itu Guru atau peneliti memberikan penjelasan lagi tentang tujuan pembelajaran dan garis besar Termodinamika.

Menjelaskan kembali tentang metode yang akan digunakan yaitu Model Pembelajaran Problems Based Learning berbantuan dengan Metode Mind Mapping serta komponen-komponennya kepada siswa. Siswa menuju kelompoknya masingmasing, setelah itu Guru atau peneliti memberikan penjelasan lagi tentang tujuan pembelajaran dan garis besar Termodinamika.

Setelah siswa bergabung ke dalam kelompknya masing-masing. Guru membagikan lembar kegiatan yang berisi petunjuk pelaksanaan percobaan untuk penemuan, kemudian menugaskan siswa untuk melaksanakannya. Dalam pelaksanaan kegiatan percobaan, Guru memberi bimbingan. Siswa melaksanakan kegiatan percobaan sesuai lembar kegiatan.

Setiap kelompok melakukan melakukan percobaan Hukum Termodinamika II. Pelaksanaan percobaan ini sebagai penerapan kedua Model Pembelajaran Problems Based Learning berbantuan dengan Metode Mind Mapping, Pelaksanaan percobaan merupakan penerapan Model Pembelajaran Problems Based Learning berbantuan dengan Metode Mind Mapping digunakan untuk menguji jawaban kelemahan siklus I).

Setelah kegiatan kelompok selesai, dilanjutkan dengan diskusi kelas yang dipandu oleh Guru untuk membahas hal-hal yang tidak atau belum terselesaikan dalam kegiatan kelompok. Selama siswa berdiskusi, Guru secara bergilir mendekati masing-masing kelompok untuk memberikan penguat serta penjelasan sesuatu hal yang belum dipahami oleh siswa. (Kegiatan diskusi adalah kegiatan Pendekatan 
Problems Based Learning berbantuan dengan Metode Mind Mapping menarik kesimpulan).

Guru atau peneliti membacakan hasil diskusi di depan kelas. Guru berperan sebagai moderator untuk membantu siswa menanggapi hasil presentasi hasil diskusi. Guru memberikan ulasan terhadap materi yang belum tersentuh oleh kerja kelompok siswa, serta memberikan ulasan terhadap materi yang belum tersentuh oleh kerja kelompok siswa. Sebagai perbaikan siklus I, Guru memberikan reward kepada siswa yang aktif dalam diskusi dan Problems Based Learning berbantuan dengan Metode Mind Mapping. Dengan iming-iming reward yang ditawarkan Guru, banyak dari siswa menjadi aktif dalam diskusi dan bertanya ataupun mengungkapkan pendapatnya, bahkan di antara kelompok mereka saling berdebat dengan positif. Secara bersamasama, Guru mengambil simpulan dan mendiskusikannya bersama siswa. Guru memberikan post tes atau quis untuk mengukur keberhasilan yang dicapai siswa.

Terdapat 5 siswa atau 14,3\% yang mendapat nilai antara $41-69$, dan 30 siswa atau $85,7 \%$ yang mendapat nilai antara $70-100$. Dengan ketentuan nilai KKM 70 , dapat disimpulkan jika pencapaian prestasi nilai $70-100$, maka prestasi belajar siswa telah meningkat dari $62,9 \%$ menjadi $85,7 \%$. Dengan $85,7 \%$ maka telah tercapai indicator pencapaian siklus II sebesar yang $85 \%$ atau lebih, maka tidak perlu dilanjutkan ke Siklus III.

Selain itu, dari proses wawancara diperoleh kesimpulan bahwa beberapa siswa menjadi bersemangat dalam belajar Fisika, karena pelaksanaan kegiatan belajar Fisika dengan pendekatan Problems Based Learning berbantuan dengan Metode Mind Mapping ini dilaksanakan dengan melibatkan masing-masing anggota kelompok, dan didiskusikan bersama kelompok sehingga mereka lebih rileks dan ringan dalam mengerjakan laporan kegiatan. Meskipun masih terdapat kendala-kendala seperti yang telah diuraikan dalam laporan observasi.

\section{PEMBAHASAN}

Berdasarkan hasil pelaksanaan pada siklus I, II dapat dinyatakan bahwa terjadi peningkatan kualitas pembelajaran yang tampak dan perolehan hasil evaluasi dan keaktifan siswa. Dari tabel 4.2 dan gambar 4.2 siklus I hasil observasi menunjukkan, prosentase keberhasilan kelengkapan menyiapkan alat dan bahan percobaan $45 \%$, prosentase keruntutan langkah-langkah yang ditempuh dalam pelaksanaan percobaan $37 \%$, prosentase keaktifan siswa dalam melaksanakan kegiatan percobaan $58 \%$, prosentase keaktifan siswa dalam mengutarakan pendapat saat berdiskusi $45 \%$ dan prosentase hasil penarikan kesimpulan akhir sesuai percobaan $46 \%$.

Berdasarkan tabel 4.5 dan gambar 4.4 siklus II hasil observasi menunjukkan, prosentase keberhasilan pendekatan kelengkapan menyiapkan alat dan bahan percobaan siswa yang disiapkan $75 \%$, prosentase keruntutan langkah-langkah yang ditempuh dalam pelaksanaan percobaan $85 \%$, prosentase keaktifan siswa dalam melaksanakan kegiatan percobaan $90 \%$, prosentase keaktifan siswa dalam mengutarakan pendapat saat berdiskusi $88 \%$ dan prosentase hasil penarikan kesimpulan akhir sesuai percobaan $84,5 \%$.

Dari daftar nilai (lihat lampiran) dapat kita lihat adanya prosentase kenaikan nilai Fisika mulai dari kondisi awal pra tindakan, diketahui baru 14 siswa atau 40\% yang mengalami ketuntasan belajar dan mendapatkan nilai sesuai dengan KKM. Hasil evaluasi siklus I menunjukkan baru 22 siswa atau 62,9\% yang mengalami ketuntasan belajar dan mendapat nilai sama dengan atau di atas KKM yaitu 70. Hal itu menunjukkan bahwa pelaksanaan siklus I belum mencapai keberhasilan, karena indicator pencapaian adalah sebesar $85 \%$ atau lebih. Siklus II menunjukkan ada 30 siswa atau $85,7 \%$ dari 35 siswa yang mengalami ketuntasan belajar. Sehingga peneliti menyimpulkan bahwa pada siklus II ini peneliti telah mencapai keberhasilan dari penelitian tindakan kelas yang telah dilakukan. 
Vol. 1 No. 1, Oktober 2017

Ketika peneliti melaksanakan siklus I, peneliti mengalami berbagai kendala antara lain masih ada siswa yang kesulitan melakukan percobaan Termodinamika. Masih ada kelompok yang bingung dalam mengikuti langkah-langkah yang tertera dalam lembar kegiatan. Masih ada beberapa siswa yang belum aktif dalam pelaksanaan percobaan. Ketika pelaksanaan diskusi, ada beberapa siswa yang tidak aktif menyampaikan pendapatnya. Dalam menyimpulkan hasil percobaan, terdapat 2 (dua) kelompok yang malu untuk presentasi, dan hanya terdapat 3 (tiga) siswa yang mengajukan pertanyaan.

Peneliti kemudian melaksanakan siklus II sebagai perbaikan siklus I, sebelum pelaksanaan siklus II ini peneliti mengganti rencana pembelajaran Model Pembelajaran Problems Based Learning berbantuan dengan Metode Mind Mapping baru yaitu dengan melakukan percobaan Hukum Termodinamika II. Dalam pelaksanaan percobaan, peneliti senantiasa memberi bimbingan untuk siswanya dalam melaksanakan langkah-langkah sesuai lembar kegiatan. Peneliti pun memberi bimbingan siswa saat berdiskusi untuk menarik kesimpulan. Dengan adanya motivasi guru berupa reward, siswa telah terlihat aktif dalam kegiatan pembelajaran dalam melaksanakan percobaan, presentasi di depan kelas dan berdiskusi menarik kesimpulan. Meskipun ada kendala yaitu siswa laki-laki tampak asyik bermain sendiri yang dibawa dan suasana menjadi gaduh, namun dengan hasil prestasi belajar yang dicapai dapat disimpulkan bahwa penelitian tindakan kelas dari siklus II ini telah berhasil.

\section{KESIMPULAN}

Penerapan pendekatan Problems Based Learning berbantuan dengan Metode Mind Mapping dapat meningkatkan Prestasi Belajar Fisika siswa Kelas XI IPA 2 SMA Negeri 1 Kalidawir Kecamatan Kalidawir Kabupaten Tulungagung. Hal ini dilihat dari prosentase kenaikan nilai Fisika siswa Kelas XI IPA 2 dari pra siklus, siklus I sampai Siklus II. Pada pra siklus, siswa yang mendapat nilai minimal 70 ada 14 siswa atau $40 \%$, pada siklus I siswa yang mendapat nilai minimal 70 ada 22 siswa atau $62,9 \%$, pada siklus II siswa yang mendapat nilai minimal 70 ada 30 siswa atau $85,7 \%$ dari 35 siswa. Dari pra siklus kemudian dilaksanakan siklus I prestasi siswa mengalami prosentase kenaikan 22,9\%. Dan dari siklus I kemudian dilaksanakan siklus II prestasi siswa mengalami prosentase kenaikan $22,9 \%$.

Penerapan pembelajaran dan prosedur dalam penelitian ini didasarkan pada pembelajaran dengan menerapkan pendekatan Problems Based Learning berbantuan dengan Metode Mind Mapping dalam pelaksanaan proses pembelajaran Fisika. Model yang dipakai dalam penelitian tindakan kelas ini adalah model siklus, adapun prosedur penelitiannya terdiri dari 2 siklus. Siklus I dilaksanakan pada hari Selasa tanggal 12 April 2016, Kompetensi Dasar 3.2 Menganalisis perubahan keadaan gas ideal dengan menerapkan hukum termodinamika. Siklus II dilaksanakan hari Selasa tanggal 19 April 2016.

Dalam setiap pelaksanaan siklus terdiri dari 4 (empat) tahapan, yaitu perencanaan tindakan, pelaksanaan, observasi, dan refleksi, kegiatan ini dilaksanakan berdaur ulang. Sebelum melaksanakan tindakan dalam tahap siklus, perlu perencanaan. Perencanaan ini memperhatikan setiap perubahan yang dicapai pada siklus sebelumnya terutama pada setiap tindakan yang dapat meningkatkan Prestasi Belajar siswa. Hal ini didasarkan pada analisis perkembangan dari pra siklus, siklus I sampai siklus II.

Berdasarkan kriteria temuan dan pembahasan hasil penelitian seperti yang diuraikan pada bab IV, maka penelitian ini dapat digunakan peneliti untuk membantu guru dalam menghadapi permasalahan yang sejenis. Disamping itu, perlu penelitian lanjut tentang upaya guru untuk mempertahankan atau menjaga dan meningkatkan prestasi belajar siswa. Pembelajaran dengan menggunakan pendekatan Problems Based Learning berbantuan dengan Metode Mind Mapping ini pada hakikatnya dapat 
digunakan dan dikembangkan oleh guru yang menghadapi permasalahan yang sejenis, terutama untuk mengatasi masalah peningkatan Prestasi Belajar siswa.

Berdasarkan hasil observasi dan pelaksanaan siklus I dan II juga dapat kita amati adanya perubahan kenaikan prosentase dalam menyiapkan alat dan bahan, keruntutan langkah-langkah siswa dalam melaksanakan percobaan, keaktifan siswa dalam melaksanakan kegiatan percobaan, keaktifan siswa ketika berdiskusi dan hasil akhir atau simpulan yang diperoleh dari hasil kegiatan diskusi.

\section{SARAN}

Berikut saran yang dapat diajukan berkaitan dengan penelitian ini, untuk melaksanakan pengembangan pembelajaran menggunakan pendekatan Problems Based Learning berbantuan dengan Metode Mind Mapping memerlukan persiapan yang cukup matang, sehingga guru harus mampu menentukan atau memilih topik yang benar-benar bisa dikembangkan dengan Pengembangan Pembelajaran menggunakan pendekatan Problems Based Learning berbantuan dengan Metode Mind Mapping dalam proses belajar mengajar sehingga memperoleh hasil yang optimal. Dalam rangka meningkatkan kualitas kinerja Guru, guru hendaknya lebih sering melatih Guru dengan berbagai pendekatan pengajaran, walau dalam taraf yang sederhana, dimana Guru nantinya dapat menemukan pengetahuan baru, memperoleh konsep dan keterampilan, sehingga Guru berhasil atau mampu memecahkan masalah-masalah yang dihadapi. Perlu adanya penelitian yang lebih lanjut, karena hasil penelitian ini hanya dilakukan di SMA Negeri 1 Kalidawir semester 1 tahun pelajaran 2015/2016, dan untuk peneltian yang serupa hendaknya dilakukan perbaikan-perbaikan agar diperoleh hasil yang lebih baik.

\section{DAFTAR RUJUKAN}

Barrows., 2001. The Tutors (Teachers) Role in Problem-Based Learning Curriculum. dari http;// edaff.siumed.edu.

Boud D. dan Felleti, G.I. 1997. The Challenge of Problem Based Learning. Londong: Kogapage

Buzan, Tony. 2003. Use Both Sides of Your Brain. Surabaya : Ikon.

Buzan, Tony. 2005. Buku Pintar Mind Maps. Jakarta : Gramedia.

Colin Rose dan Malcolm J. 2006. Accelered Learning. Bandung : Nusantara.

Dimiyati dan Mudjiono. 2002. Belajar dan Pembelajaran. Jakarta: Rineka Cipta

Dimyati \& Mudjiono, 2006. Belajar dan Pembelajaran. Jakarta: Rineka Cipta.

Djamarah, Syaiful Bahri. 2002. Psikologi Belajar. Jakarta : PT. Rineka Cipta

Edwin, Bridges. 1992. Problem Based Learning for administrators. America; ERIC

Cleaning House on Educational Management

Fudyartanto, Ki RBS. 2002. Psikologi Pendidikan dengan Pendekatan Baru.

Yogyakarta: Global Pustaka IImu

Hayinah. 1992. Masalah Belajar, Malang: IKIP Negri Malang.

Ibrahim, Muslimin dan Nur. 2000. Pembelajaran Berdasarkan Masalah. Surabaya: UNESA

Ibrahim, Muslimin dkk. 2005. Pembelajaran Kooperatif. Surabaya: UNESA.

Kemmis, S. dan R. Mc Taggart. 1988. The Action Research Planner. Victoria: Deakin University.

Mierson. 2004. A Problem-Based Learning Course in Physiology for Undergraduate and Graduate basic Science Student"s. dari http://edaff.siumed.edu

Pannen, P. dan Sadjati, I. M. 2001. Pembelajaran Orang Dewasa . Jakarta: PAU-PPAI. Universitas Terbuka.

Prayudi. 2008. Mind mapping. Online:http://prayudi.wordpress.com/mind-mapping/. (diakses 5 februari 2013)

Purnomo, Daniko. 2012. Hubungan AntaraPemahaman Materi, Motivasi Belajar, Dan Prestasi Belajar. Fakultas Psikologi: Universitas Ahmad Dahlan Yogyakarta 
JURNAL PENDIDIKAN: Riset \& Konseptual

Vol. 1 No. 1, Oktober 2017

Riyanto, Yatim. 2010. Paradigma Baru Pembelajaran. Jakarta : Kencana Pernada Group.

Slavin, R. E. 1994. Educational Psychology Theory Into Practices. 4th ed. Boston: Ally and Bacon Publishers.

Syah. M. 2003. Psikologi Belajar. Jakarta: PT. Raja Grafindo Persada 